\title{
A "memória herdada": as comissões da verdade e os "escrachos" promovidos pela juventude em países da América Latina, como Argentina, Chile e Brasil
}

\author{
The "inherited memory": truth commissions and "escrachos" promoted by youth \\ in Latin American countries such as Argentina, Chile and Brazil
}

Marta Gouveia de Oliveira Rovai ${ }^{1}$

\section{Resumo}

Este artigo apresenta um breve histórico da justiça de transição em países da América Latina, como Argentina, Chile e Brasil, baseada na busca pela verdade, justiça e reparação. Num primeiro momento mostra a importância das comissões da verdade, criadas para revelar as violações cometidas durante os regimes ditatoriais. Em seguida trabalha com o conceito de "memória herdada", de Michael Pollak, para mostrar como parcelas organizadas da juventude atuam no presente denunciando publicamente, por meio de manifestações conhecidas como "escrachos", os responsáveis pelos crimes cometidos contra a geração de seus pais e avós. No Brasil, destaca-se o Levante Popular da Juventude que, inspirado no movimento dos HIJOS, na Argentina, toma para si o dever do compartilhamento da memória.

Palavras-chave: justiça de transição; memória herdada; juventude latino-americana

\begin{abstract}
This article presents a brief history of transitional justice in Latin American countries such as Argentina, Chile and Brazil, based on the search for truth, justice and reparation. At first shows the importance of truth commissions, created to reveal the violations committed during the dictatorial regimes. Then explores the concept of "inherited memory", as that of Michael Pollak, to show how organized youth installments presently act in publicly denouncing, through demonstrations known as "escrachos", those responsible for the crimes committed against their parents and grandparents generations. In Brazil, there is the Levante Popular da Juventude that, inspired by the movement of HIJOS, in Argentina, takes on the duty of sharing memory.
\end{abstract}

Keywords: transitional justice; inherited memory; Latin American youth

Artigo recebido em: 30 /01/2015.

Artigo aceito para publicação em: 21/06/2015.

\footnotetext{
${ }^{1}$ Marta Gouveia de Oliveira Rovai: Doutora em História Social pela Universidade de São Paulo, Professora Adjunta da Universidade Federal de Alfenas (UNIFAL-MG). Email: martarovai@usp ou marta.rovai@unifal-mg.edu.br.
}

\section{CANPHLAC}

Revista Eletrônica da ANPHLAC, ISSN 1679-1061, № . 18, p. 223-250, jan./jul. 2015. http://revista.anphlac.org.br/ 


\section{Apresentação}

Após dois anos e sete meses de investigação, a Comissão Nacional da Verdade (CNV) concluiu oficialmente seu trabalho, entre maio de 2012 e dezembro de 2014, tendo chegado ao saldo que revela, em parte, as atrocidades cometidas em 20 anos de ditadura civil-militar no Brasil: 6016 denúncias de tortura; a existência de 230 locais, oficiais ou clandestinos, de práticas das violações; 536 intervenções em sindicatos; 6591 militares perseguidos, revelando que o apoio militar ao regime não era consensual; 377 agentes da repressão; e 434 mortos (incluindo-se aqui os chamados "desaparecidos"). ${ }^{2}$

O resultado da investigação é fruto de um longo processo de transição democrática, que não se encerrou com a entrega do relatório à presidente Dilma Rousseff. Pelo contrário, deve ampliar ainda mais a discussão em torno das disputas pela memória e testemunho daqueles que foram vítimas ${ }^{3}$, valorizando a histórica luta contra a violação dos direitos humanos cometida em diferentes países da América Latina, entre as décadas de 1960 e 1980.

A chamada Justiça de Transição, que hoje caracteriza as ações promovidas pelos Estados latino-americanos, é entendida pela Organização das Nações Unidas (ONU) como os mecanismos e as estratégias que são utilizados para lidar com a herança de violência e os traumas coletivos dos regimes autoritários e promover o direito à memória, à verdade e à justiça ${ }^{4}$. Parte-se do entendimento de que o aperfeiçoamento da democracia implica encarar o passado, mesmo que ele seja doloroso. Nesse sentido, a constituição de comissões da verdade em países como Argentina, Uruguai, Peru,

\footnotetext{
${ }^{2}$ Segundo dados do relatório final da Comissão Nacional da Verdade, "sendo 191 os mortos, 210 os desaparecidos e 33 os desaparecidos cujos corpos tiveram seu paradeiro posteriormente localizado..." (CNV, 2014, p. 963)

${ }^{3}$ Segundo resolução da ONU, de 1985, "Se entenderá por 'vítimas' as pessoas que, individual ou coletivamente, tenham sofrido danos, inclusive lesões físicas ou mentais, sofrimento emocional, perda financeira ou menosprezo substancial dos seus direitos fundamentais, como consequência de ações ou omissões que violem a legislação penal vigente nos Estados membros, inclusive a que proscreve abuso de poder."

${ }^{4}$ Justiça de Transição ou Justiça Transicional, segundo Esteban Cuya, refere-se ao "conjunto de medidas direcionadas a superar os graves danos causados à sociedade por regimes totalitários e/ou ditatoriais que, em contextos de anomalia constitucional, cometem violações aos direitos humanos contra pessoas ou grupos de uma determinada nação" (2011, p. 40). São seus componentes básicos a justiça, a verdade, as reformas políticas e a reparação aos danos.
}

\section{CANPHLAC}

Revista Eletrônica da ANPHLAC, ISSN 1679-1061, No. 18, p. 223-250, jan./jul. 2015. http://revista.anphlac.org.br/ 
Guatemala, Chile, Paraguai e Brasil ocorreu em um contexto de reconhecimento de graves crimes contra os direitos humanos, da necessidade de reparação e de responsabilização, em oposição à edição de leis de anistia que, durante muito tempo, favoreceram a impunidade de perpetradores, o esquecimento e o silenciamento dos que sofreram com as perseguições.

As leis de anistia, chanceladas pelos próprios militares, não apenas no Brasil, impediu discussões mais aprofundadas sobre as feridas abertas, a violência, os algozes, as culpas e punições. Em alguns discursos, o uso de expressões como revolução, subversão, crimes conexos, reconciliação, interrogatórios e desaparecidos serviu - e ainda serve - para omitir ou substituir golpe, ditadura, resistência, crimes contra a humanidade, justiça, torturas e mortos, respectivamente, como uma estratégia de certos setores mais conservadores e ligados às ditaduras para afastar o debate sobre os crimes cometidos e, assim, construir uma memória de conciliação, contra o que chamaram de "revanchismo".

Essa linguagem, no entanto, não convenceu os "sobreviventes" dessas violações e os ativistas pelos direitos humanos que entenderam que seus testemunhos, durante tanto tempo silenciados, relativos à censura, às torturas, às mortes e aos exílios, deveriam ser "doados" à comunidade que não os vivenciou, a fim de que o dolo e a ferida fossem expostos publicamente e promovessem a reflexão sobre um problema que deveria ser entendido como coletivo.

O conhecimento sobre as experiências, nesse sentido, deveria modificar o presente. Haveria, assim, ainda uma dívida com o passado, com os que pereceram, e com o presente, com aqueles que nada sabiam sobre as violações perpetradas, potencialmente contra a dignidade de qualquer pessoa. Para que esse direito e dever de memória se realizassem de fato era preciso tornar pública cada história, reivindicar a nomeação dos culpados, a responsabilização e as reparações, estabelecendo-se um confronto político, histórico e até mesmo jurídico entre os que apoiaram e os que resistiram aos regimes autoritários. Tornar público significa dar acesso aos fatos e seus significados às gerações posteriores, levadas a herdar uma memória que não lhes pertence diretamente, mas que passa a fazer sentido em sua vivência no presente.

\section{CANPHLAC}

Revista Eletrônica da ANPHLAC, ISSN 1679-1061, №. 18, p. 223-250, jan./jul. 2015. http://revista.anphlac.org.br/ 
Desta forma, este artigo pretende fazer um breve balanço da importância da criação das comissões da verdade, em alguns países como Argentina, Chile e Brasil, como um importante passo na construção da Justiça de Transição e, mais do que isso, procura atentar na atuação das gerações nascidas após o término das ditaduras e que, portanto, estão longe de manter diretamente vínculos ou memórias sobre quaisquer acontecimentos ocorridos entre os anos de 1964 e 1984. No entanto, as ações de parcela organizada da juventude latino-americana, hoje, tomam para si a responsabilidade por cobrar políticas públicas mais eficazes a fim de garantir o acesso à informação, o julgamento e a reparação aos crimes cometidos contra as gerações anteriores. Nos dois primeiros países isso pode ser percebido em parte da juventude, geralmente filhos ou netos das vítimas que, a partir do final do século XX e início do XXI, tomou o espaço público na forma de manifestações conhecidas como "escrachos", com o objetivo de denunciar as barbaridades e exigir a justiça histórica, jurídica e moral a seus antepassados.

Especialmente no Brasil, mais recentemente, movimento semelhante nasceu e continua a atuar, liderado pelo Levante Popular da Juventude, organização nascida em 2006, em Porto Alegre (mas que promove ações em todo o País) e que tem desenvolvido o esclarecimento público, por meio dos chamados esculachos, inspirados nos jovens argentinos e chilenos.

Em torno das experiências desses jovens brasileiros, procura-se evidenciar a constituição de uma "memória herdada", assim como define Michael Pollak (1992), sob um novo contexto político e social, de transição democrática. No campo da memória, repleto de conflitos, no qual as narrativas das vítimas das ditaduras sustentam a ideia do "nunca mais", importa saber o que significa para as novas gerações envolver-se num processo em torno de algo que não vivenciaram, por quais meios recriam a memória das gerações anteriores e, ao mesmo tempo, projetam o futuro do país. O que pode representar o conceito de "nunca mais" para os jovens, numa sociedade em que o

\section{GANPHLAC}

Revista Eletrônica da ANPHLAC, ISSN 1679-1061, № . 18, p. 223-250, jan./jul. 2015. http://revista.anphlac.org.br/ 
estímulo é viver o presente e esquecer o passado, este último visto como obstáculo ao futuro $?^{5}$

Para finalizar, o artigo apresenta parte dessas ações promovidas pelo Levante, sua militância nos "escrachos" ou "esculachos" nos últimos anos, com a intenção de compreender as apropriações, por parte desses jovens, da memória e da história, com recriação de sentidos e elaboração de novos meios para sua atuação política no presente e para a formação de uma identificação com o passado histórico.

\section{A memória herdada pelas gerações após as ditaduras}

Autores como Pierre Nora (1993), Zygmunt Bauman (2005) e François Hartog (2006) voltaram-se ao debate em torno da necessidade social da memória, num mundo marcado pela velocidade capitalista, pelo avanço da tecnologia e pela crise da tradição, em que se promove o desenvolvimento de inúmeras identidades. Bauman (2005) chegou a manifestar sua preocupação com a existência do que chamou "comunidades guarda-roupas" ou "estéticas", em que as identidades são formadas e dissolvidas com a rapidez das relações fluidas, superficiais e efêmeras, que se descolam da memória.

Hartog e Nora apontaram para o paradoxo da crise e, ao mesmo tempo, o excesso de memórias, numa luta contra a dissolução das tradições, em busca de novas identidades, novas formas de entender o passado, por meio de "lugares de memórias" ou das "memórias dos lugares", de pessoas e eventos. Para isso, referências são construídas ou fortalecidas de modo a se constituir um "novo regime de historicidade", o que seria, para Hartog, a consciência que uma sociedade tem sobre si na relação com seu passado,

\footnotetext{
${ }^{5}$ Este texto se baseia em pesquisa de história oral, ainda em fase inicial de desenvolvimento, sobre as experiências de jovens militantes do Levante Popular da Juventude, em escrachos realizados em São Paulo e Minas Gerais, desde 2012.
}

\section{CANPHLAC}

Revista Eletrônica da ANPHLAC, ISSN 1679-1061, Nº 18, p. 223-250, jan./jul. 2015. http://revista.anphlac.org.br/ 
enquanto aprendizado com a experiência, e também necessária à projeção de futuro e à espera.

Esse conflito entre o imediatismo do presente e a necessidade de se tomar o passado como referência atuaria sobre as novas gerações que, tendo acesso rapidamente às informações pela internet e pressionada pelo mercado de trabalho cada vez mais dinâmico e seletivo, estariam vivenciando novas experiências que as afastariam de forma cada vez mais intensa das velhas gerações e instituições, cujos valores se tornariam estranhos diante de novas demandas. Uma memória mais pragmática, recente e fluida se constituiria, diferentemente do conhecimento acumulado, do ensinamento do passado, considerado por elas, muitas vezes, ultrapassado.

Para Silvio C. O. Benevides e Sóstenes Aroeira da Luz (2010), no entanto, no turbilhão de acontecimentos marcado pelo processo de globalização, novas demandas se apresentam, além do consumo, e uma nova "cidadania juvenil" está se formando; não vazia de utopias, como considerada muitas vezes pela mídia e por intelectuais, mas repleta de novas dimensões para além das formas tradicionais de organização política diga-se partidária e sindical - ainda praticadas e consideradas sinônimo de politização. Para os autores, haveria uma reformulação teórica da noção de identidade coletiva e uma nova forma de engajamento de parcela dos jovens sob outras óticas, considerandose a multiplicidade de relações e significações sociais, os interesses éticos, ambientais e um novo tipo de interação com diferentes experiências sociais.

Por ligar essas duas dimensões, a vida politizada traz para o primeiro plano questões morais e, até mesmo, existenciais normalmente negligenciadas pelas instituições centrais da modernidade. Essas questões demandam uma remoralização da vida social em todas as esferas, das mais íntimas às mais universais. Por essa razão, os problemas que a política-vida busca suplantar não se enquadram de maneira fácil aos padrões que usualmente orientam a política institucionalizada. Tal visão de vida politizada, também, se caracteriza por possibilitar uma ação individual e coletiva, que pode promover o surgimento de variadas formas políticas que se distinguem, sobremaneira, daquelas predominantes no âmbito dos Estados e das esferas de interação global (BENEVIDES; LUZ, 2010, p. 1).

\section{CANPHLAC}

Revista Eletrônica da ANPHLAC, ISSN 1679-1061, №. 18, p. 223-250, jan./jul. 2015. http://revista.anphlac.org.br/ 
Essa diversidade de demandas, marcada pelo mundo mais fluido e globalizado, trouxe também novas formas de lidar com a memória. Michael Pollak (1992), ao discutir os elementos da memória, afirmou que aas lembranças dos indivíduos são alimentadas por três dimensões: os acontecimentos vividos diretamente; os fatos experimentados por tabela e aqueles aos quais ele chamou de memória herdada.

\footnotetext{
Em primeiro lugar, são os acontecimentos vividos pessoalmente. Em segundo lugar, são acontecimentos que eu chamaria de "vividos por tabela", ou seja, acontecimentos vividos pelo grupo ou pela coletividade à qual a pessoa se sente pertencer. São acontecimentos dos quais a pessoa nem sempre participou mas que, no imaginário, tomaram tamanho relevo que, no fim das contas, é quase impossível que ela consiga saber se participou ou não. Se formos mais longe, a esses acontecimentos vividos por tabela vêm se juntar todos os eventos que não se situam dentro do espaço-tempo de uma pessoa ou de um grupo. É perfeitamente possível que, por meio da socialização política, ou da socialização histórica, ocorra um fenômeno de projeção ou de identificação com determinado passado, tão forte que podemos falar numa memória quase que herdada (POLLAK, 1992, p. 201).
}

A memória herdada envolve a vinculação a uma lembrança de personagens, fatos e lugares que acabam se transformando quase que em conhecidos, mesmo que aqueles que lembrem não tenham pertencido ao mesmo espaço-tempo; são projeções e transferências, pois não se referem à vida física das pessoas. A memória individual e coletiva também sofre flutuações em face do momento em que ela é articulada, em que ela está sendo expressa. As preocupações do momento - mais amplas e múltiplas para as novas gerações - constituem um elemento de estruturação da memória coletiva no presente, apropriando-se, socializando e ressignificando os eventos relacionados a gerações anteriores.

Inserida no contexto de transição democrática, parcelas de jovens, na América Latina, envolveram-se em movimentos que relembram as vítimas, questionam a ditadura e se confrontam com grupos apoiadores do golpe de 1964. Seriam eles parte, para usar uma expressão de Johan Michel (2010), dos "empreendedores da memória", aqueles que se organizam no sentido de perpetuar as lembranças das violações,

\section{GANPHLAC}

Revista Eletrônica da ANPHLAC, ISSN 1679-1061, No. 18, p. 223-250, jan./jul. 2015. http://revista.anphlac.org.br/ 
continuadores da luta pelo reconhecimento das vítimas e pela exigência de ações efetivas de responsabilização, justiça e reparação.

As ações desses "empreendedores" (tais como as várias organizações sindicais, políticas e estudantis, as associações e comissões da sociedade civil, assim como as instituições governamentais) se direcionam a deixar claro e amplo o debate em torno das divergências sobre a verdade histórica e dos significados dos fatos sobre as subjetividades e a coletividade. Assim, as memórias, especialmente a dos presos e perseguidos políticos, sobre o período ditatorial na América Latina tornam-se o epicentro das políticas públicas de reparação, sendo reconhecidas e apropriadas pelas novas gerações, que tomam para si a cobrança de um passado que se presentifica e compromete o futuro.

Esse último elemento da memória - sua organização em face das preocupações pessoais e políticas do momento presente - mostra que ela é um fenômeno construído, de forma consciente ou não, e provoca a seleção de lembranças e a constituição de identidades, uma vez que permite a noção de pertencimento a uma coletividade e a continuidade de um grupo. O sentimento de permanência de um momento em aberto as referências às lembranças que pertencem a outros mas que são tomadas como suas parece marcar o comportamento de militantes de certos setores juvenis, um pouco diferente dos filhos de desaparecidos e mortos (mais diretamente afetados pelas ações das ditaduras latino-americanas pela ausência de seus pais), e orienta parte de suas ações, principalmente aquelas relacionadas ao passado histórico da ditadura militar e ao planejamento do futuro mais democrático. Dessa forma, como afirma Pollak sobre a memória,

Podemos portanto dizer que [...] é um elemento constituinte do sentimento de identidade, tanto individual como coletiva, na medida em que ela é também um fator extremamente importante do sentimento de continuidade e de coerência de uma pessoa ou de um grupo em sua reconstrução de si (POLLAK, 1992, p. 200-212).

\section{GANPHLAC}

Revista Eletrônica da ANPHLAC, ISSN 1679-1061, No. 18, p. 223-250, jan./jul. 2015. http://revista.anphlac.org.br/ 
Como um passado indisponível às novas gerações, a memória torna-se refém do trauma histórico, e corre-se o risco de repeti-lo. Pelo contrário, para quem não vivenciou o período dos regimes autoritários na América Latina, aquilo que foi vivido pelos antecessores pode ser conhecido por meio das narrativas das vítimas (o centro da justiça de transição) - que o representam e significam - e pode ser compartilhado na forma também de testemunho, aqui não no sentido de quem experimentou, mas de quem ouve e é capaz de se colocar no lugar do outro, apesar da diferença geracional. Trata-se, em certo sentido, do que Luísa Passerini (2006) chamou de intersubjetividade, quando as memórias se entrelaçam constituindo uma identidade que, embora subjetiva, é também coletiva em torno dos mesmos fatos e referências, mesmo que seus sentidos sejam recriados.

\section{As comissões da verdade e os escrachos na América Latina}

De acordo com Maurice Halbwachs (2006), a memória se dá, em última instância, nas pessoas, uma vez que são elas que detêm as lembranças. Mesmo assim, a memória coletiva é constituída de experiências passadas e vivenciadas social e culturalmente, que fornecem as referências para as recordações individuais, mesmo entre gerações diferentes. O que uma criança ou jovem lembra, mesmo de forma particular, está contaminado por signos, ensinamentos e dizeres dos mais velhos.

Seguindo essa percepção, assim como as diferentes formas de lembrar, seja individual ou coletivamente, defendidas por Michael Pollak, pode-se considerar que o que ele designa como "memória vivida" estaria relacionado àqueles que hoje dão seu testemunho - como os que relataram suas histórias à Comissão da Verdade - sobre a resistência contra as ditaduras latino-americanas, a perseguição, as sevícias sofridas e, muitas vezes, o exílio, todos esses experimentados diretamente. Essas pessoas formariam a primeira geração de memória que se mobiliza e se posiciona em torno do direito de lembrar, contra a política de esquecimento que perdurou e o silenciamento, mantidos pela anistia oficializada pelo Estado desde 1979.

A "memória por tabela" (Pollak, 1992) seria aquela vivenciada pelos familiares e amigos de perseguidos, mortos e considerados "desaparecidos" políticos, e que

\section{CANPHLAC}

Revista Eletrônica da ANPHLAC, ISSN 1679-1061, №. 18, p. 223-250, jan./jul. 2015. http://revista.anphlac.org.br/ 
também sofreram torturas - senão físicas, emocionais -, guardaram traumas e sentiram os tentáculos do regime violento e destruidor de subjetividades e coletividades, na invasão de suas casas, na desestruturação da vida cotidiana e no desaparecimento forçado de seus entes queridos. Estes formaram os grupos que em praticamente toda a América Latina se mobilizaram em torno do reconhecimento das vítimas, da reparação e da justiça.

Foram essas pessoas - diretamente reprimidas por sua ligação aos grupos armados, estudantis, sindicais e religiosos, ou parentes daqueles que pereceram - que pressionaram para que, após o término das ditaduras, a verdade sobre a violência viesse à tona. Graças a elas, em 1984 vários países, dentre eles Brasil, Uruguai, Argentina, Guatemala, El Salvador e Paraguai, elaboraram e assinaram a Convenção Interamericana para Prevenir e Punir a Tortura, considerando a tortura uma ofensa e um crime sob sujeição jurídica universal. Essa decisão levou ao debate em torno da responsabilização pelos desaparecimentos forçados nas ditaduras latino-americanas, sendo Honduras o primeiro país a ser punido por promover o desaparecimento de 180 pessoas, entre 1981 e 1984. Esse movimento deu origem, também, em 1996, à Convenção Interamericana sobre Desaparecimento Forçado de Pessoas, entendendo-se o desaparecimento como "crime contra a humanidade", por ser uma ofensa contínua e permanente, sem conclusão, e, portanto, não submetido às leis de anistia e violência imprescritível (Sikkink, 2011).

No caso da Argentina, ao fim do período militar esta primeira geração cobrou que nomes de perpetradores, lugares e eventos de torturas, mortes e desparecimentos fossem esclarecidos e publicizados. Em 1985, com a transição democrática, o presidente Raul Alfonsín criou a junta de julgamentos, a Comisión Nacional sobre Desaparición de Personas (Conadep) e anulou a lei de autoanistia, atribuída pelos próprios militares a fim de controlar o processo. Nesse momento, também, foi publicado o livro Nunca Más, organizado por Ernesto Sábato, que acabou por reforçar o movimento com o mesmo nome que se estendeu a vários países da América Latina,

\section{CANPHLAC}

Revista Eletrônica da ANPHLAC, ISSN 1679-1061, No. 18, p. 223-250, jan./jul. 2015. http://revista.anphlac.org.br/ 
inclusive o Brasil, que publicou obra homônima no mesmo ano, sob a organização de D. Paulo Evaristo Arns e pelo pastor prebisteriano James Wright. ${ }^{6}$

No entanto, a pressão de setores militares que temiam ser processados e perder seus privilégios fez com que Alfonsín chegasse a sancionar as leis do Ponto Final e da Obediência Devida, procurando justificar as ações de policiais, militares e torturadores como fruto de "ordens de cima" e livrá-los do julgamento por torturas e mortes. Esse acontecimento garantiu a mais de 2 mil deles, momentaneamente, a impunidade por seus crimes. Posteriormente, o governo de seu sucessor, Carlos Menem, perdoou militares, inclusive os que já estavam presos, pelas violações cometidas, por entender que, uma vez votadas pelo Congresso Nacional, as referidas leis representavam a vontade popular e era um avanço na democracia. Optou-se, então, pela reparação econômica de vítimas diretas e familiares de mortos e desaparecidos, o que foi seguido, mais tarde, pelo Brasil, durante o governo do presidente Fernando Henrique Cardoso, numa política de compensação econômica que as argentinas Madres da Plaza de Mayo sempre condenaram. A Agrupación Abuelas de Plaza de Mayo, fundada no mesmo ano da associação de mães que exigiam os corpos de seus filhos assassinados (1977), liderou o movimento pela punição de crimes de sequestro, apropriação e falsificação de identidade das crianças (seus netos e netas), filhas de opositores mortos (seus filhos), a maioria sob tortura na Escola Naval de Mecânica (ESMA), um centro de interrogatórios. Defendendo que esses crimes seriam imprescritíveis, pois, sem conclusão, esse movimento conseguiu a condenação de presidentes, como o general Jorge Videla, acusado pelo desaparecimento forçado de pelo menos 500 crianças.

De acordo ainda com Katryn Sikkin, em 1998 a Organização das Nações Unidas instituiu o Estatuto de Roma, do qual o Brasil foi signatário, e criou o Tribunal Penal Internacional, considerando que qualquer pessoa ou Estado não poderia se eximir de qualquer julgamento ou responsabilização da pena. Isso resultou, pela primeira vez na prática, na prisão do ditador chileno Augusto Pinochet, que havia permanecido no poder

\footnotetext{
${ }^{6}$ O livro argentino Nunca Más e a versão homônima brasileira tiveram grande impacto sobre a América Latina, na medida em que ambos trouxeram dados e depoimentos relativos à tortura, ao assassinato e ao desaparecimento forçado de pessoas, pela primeira vez; no caso do Brasil, ainda em plena ditadura.
}

\section{ANPPLAC}

Revista Eletrônica da ANPHLAC, ISSN 1679-1061, No. 18, p. 223-250, jan./jul. 2015. http://revista.anphlac.org.br/ 
por 17 anos e que, numa decisão conjunta entre Espanha e Inglaterra, teve sua prisão decretada e foi julgado por crimes contra a humanidade, como a tortura e o desaparecimento de milhares de pessoas em seu país. O "efeito Pinochet" promoveu uma onde de protestos e reivindicações de prisões em seus vizinhos, que haviam passado por experiência semelhante de repressão, perseguição e mortes, e abriu a perspectiva da possibilidade de processos judiciais contra perpetradores.

No Chile, após o final do governo Pinochet (1973-1990), havia sido criada a Comissão Nacional da Verdade e Reconciliação (Comisión Nacional para la Verdad y Reconciliación) para investigar os casos de violações dos direitos humanos no país. Além dela, foram criadas a Oficina Nacional do Retorno, também em 1990, e a Corporação Nacional de Reparo e Reconciliação, em 1991 (PINTO, 2010).

Essa sucessão de organizações, encabeçadas pela geração que sofreu diretamente com a violência do regime, demonstrou um avanço no debate e mobilização pelas reparações, mas pouco conseguiu crescer no sentido jurídico, pois as investigações e punições ficaram restritas aos crimes de assassinato político, e seus membros não conseguiram realizar a prisão de torturadores. A primeira Comissão da Verdade e Reconciliação, conhecida como Rettig, tinha como finalidade a "busca da verdade", com o reconhecimento, mas não a punição, dos autores de violações. Como consequência, nenhum militar ou torturador foi julgado ou condenado. A pressão da sociedade civil chilena - fortemente dividida entre opositores e apoiadores de Pinochet, principalmente após sua prisão em 1998 - levou a que, em 2003, ela fosse reativada como Comissão da Verdade sobre Prisão e Tortura, ou Comissão Valech, em homenagem ao bispo Santiago Sérgio Valech, que a coordenou até 2010.

Apesar das comissões da verdade em toda a América Latina andarem a passos lentos do ponto de vista jurídico, sua criação impulsionou o que Beatriz Sarlo (2006) chamou de "boom de subjetividades", no processo de políticas de transição, em que questões como memória e testemunho passaram a ser centrais no debate político. Viu-se constituir, cada vez com mais força, a condição de uma memória herdada pelas novas gerações, que passaram a se identificar com o passado a partir da defesa dos direitos

\section{GANPHLAC}

Revista Eletrônica da ANPHLAC, ISSN 1679-1061, No. 18, p. 223-250, jan./jul. 2015. http://revista.anphlac.org.br/ 
humanos e da construção de um país mais democrático. Esse processo foi intitulado por Sikkink (2011) como "justiça em cascata":

[...] esses processos constituem uma tendência nova, dramática e interelacionada na política mundial, voltada à responsabilização criminal individual de agentes públicos, alguns dos quais chefes de Estado, por violações dos direitos humanos. Essa tendência é referenciada como justiça em cascata (justice cascade). [...] Justiça em cascata é a abreviação que usei para me referir à mudança dramática na legitimidade das leis de responsabilização penal individual por violações dos direitos humanos e um aumento nas ações (processos) em nome dessas leis (SIKKINK, p. 33-34, 2011).

Nesse sentido, a mobilização, para além do direito jurídico, é tomada como dever moral e ético não apenas de quem sofreu diretamente com a violência, mas também das gerações posteriores, condenadas ao risco da repetição, formando-se uma corrente "pró-mudança" a partir do reconhecimento das violações, da escuta das vítimas e da nomeação dos responsáveis (Sikkink, 2011). Com o fim das ditaduras em diversos países latino-americanos, entre os anos de 1980 e 1990, a expressão "Nunca Mais" passou a ser uma bandeira de luta para que as "memórias subterrâneas" pudessem emergir e fizessem parte da disputa em torno de versões sobre o passado, para que as experiências relacionadas à violação dos direitos humanos pudessem ensinar as novas gerações e ajudar a evitar novos erros no presente e no futuro.

As marcas do trauma coletivo fizeram-se sentir no presente por uma geração já nascida na transição democrática, muitas vezes formada não somente pelos filhos ou netos dos perseguidos políticos, mas por jovens que até recentemente desconheciam os fatos relacionados à ditadura e que estiveram distanciados no tempo e no espaço desses momentos sombrios. No entanto, os questionamentos sobre o destino dos desaparecidos políticos em toda a América Latina, a partir do final dos anos 1980 e 1990, acabaram por atingi-los, seja por meio da mídia, pela educação nas universidades ou pelo envolvimento nos movimentos sociais. Em especial na Argentina, um dos primeiros agrupamentos de jovens foi protagonizado pelos HIJOS (sigla em espanhol para Filhos e Filhas pela Identidade, Justiça e contra o Esquecimento e o Silêncio), descendentes de

\section{CANPHLAC}

Revista Eletrônica da ANPHLAC, ISSN 1679-1061, №. 18, p. 223-250, jan./jul. 2015. http://revista.anphlac.org.br/ 
mortos e "desaparecidos" políticos, a partir de suas experiências de angústia e busca pela identidade.

Tanto na Argentina como no Chile, exemplos significativos da luta pela verdade e contra a impunidade, o processo de anistia e/ou de lentidão dos julgamentos e das reparações promoveu protestos desses jovens, dando-se origem aos chamados "escrachos", por meio dos quais eles assumiam o papel de denunciar os torturadores e assassinos de seus pais, com manifestações diante de suas casas, exibição e publicação de nomes, para que a justiça moral forçasse a realização da jurídica. Na Argentina, essas ações lideradas pelos HIJOS, reinventando o espaço público, ampliaram o debate político sobre o passado histórico e os direitos humanos. Assim, jovens com vinte e poucos anos responderam às políticas de esquecimento com o lema "si no há justicia, hay escraches".

Os filhos dos "desaparecidos" e mortos tocaram a vivência de outros jovens e colocaram em evidência um dever de memória a toda uma geração cuja idade se assemelhava a de seus pais no período ditatorial e que parecia, em certa medida, querer ocupar o vazio político deixado pela ausência deles, em nome deles. A memória herdada deixa em evidência uma "história aberta", como chamaria Walter Benjamin (1997), um passado que se presentificaria pelos ensinamentos e pelas expectativas futuras em torno de uma construção democrática, das quais esses jovens querem ser protagonistas, como em outro momento histórico seus antepassados quiseram ser, por outros meios.

Os "escrachos", que nasceram em 1995 na Argentina - ou "funas", como foram chamados no Chile - apresentaram-se como novas táticas de luta, marcadas por novas simbologias políticas e uma forma de ocupação "festiva" do espaço público, chamando atenção da coletividade para a lembrança. A perspectiva de mudança, da esperança de um novo futuro a partir do conhecimento do passado, procurou superar a dor, o desamparo daqueles que ficaram pelo caminho, o esquecimento forçado, a juventude incompleta daqueles que pereceram. A atuação pública desses jovens torna traumas particulares em problemas históricos e coletivos, em busca de justiça moral e jurídica. Questões como violações físicas e psíquicas, a ausência dos corpos, a falta de

\section{CANPHLAC}

Revista Eletrônica da ANPHLAC, ISSN 1679-1061, No. 18, p. 223-250, jan./jul. 2015. http://revista.anphlac.org.br/ 
julgamento e punição dos responsáveis, deixaram de ser próprias das famílias ou das pessoas que sofreram com as ações, ou seja, um problema da geração passada transforma-se em perguntas universais, sempre atuais. A denúncia nas praças, nas ruas e nas casas de algozes, por meio do barulho, de gritos, de música, de cartazes e pichações, colocou em visibilidade aquilo que poderia ser uma memória ou uma dor privada.

Procura-se, assim, romper com o silenciamento imposto pela repressão do Estado e pela história oficializada do vencedor que encerra em espaços íntimos as lembranças e as dores mais traumáticas; pela violência de quem calou; pela indiferença de quem não vivenciou. O esquecimento como dever ou apatia, alimentado pela ausência de respostas jurídicas e institucionais sobre a abertura de arquivos e responsabilizações sobre mortos, desaparecidos, enlouquecidos ou esquecidos, foi combatido pela publicização de nomes, lugares e datas.

Esses movimentos argentinos e chilenos acabaram por inspirar a criação de ações parecidas no Brasil. Os jovens brasileiros que nasceram após a ditadura civilmilitar foram considerados, muitas vezes, a geração marcada pelo hiperconsumo e pela ausência de pautas políticas e sociais. No entanto, assiste-se ao nascimento de diferentes agrupamentos políticos e sociais de caráter juvenil; o Levante Popular da Juventude é aquele que mais se assemelha ao que os HIJOS fizeram na Argentina, em que se colabora para a constituição de uma identidade voltada para a cidadania e para os direitos humanos.

\section{A Comissão Nacional da Verdade no Brasil}

Inserida nesse contexto de justiça de transição "em cascata”, a atuação da CNV é fruto de longa persistência de parte da sociedade brasileira contra o esquecimento forçado. Ainda durante a ditadura civil-militar brasileira, presos e seus familiares desafiaram a recusa do governo em assumir a prática de graves violações, por meio de greves de fome e da elaboração de um documento conhecido como "Bagulhão", pelo qual faziam denúncias das condições carcerárias. Junto a isso, o Movimento Feminino pela Anistia, em 1975, e o Comitê Brasileiro pela Anistia, em 1978 - ambos criados pela

\section{GANPHLAC}

Revista Eletrônica da ANPHLAC, ISSN 1679-1061, No. 18, p. 223-250, jan./jul. 2015. http://revista.anphlac.org.br/ 
sociedade civil - reivindicaram a anistia "ampla, geral e irrestrita” aos presos e exilados políticos, assim como a punição a torturadores.

Em 1985 nasceu o projeto Brasil: nunca mais, sob a coordenação do cardeal d. Paulo Evaristo Arns e do reverendo Paulo Wright, a mais organizada iniciativa de denúncia das barbaridades praticadas durante a ditadura, com apresentação de depoimentos sobre torturas em órgãos repressivos do governo e em lugares clandestinos, nos quais muitos foram assassinados. Nesse contexto organizou-se, também, em 1995, o Dossiê de mortos e desaparecidos políticos a partir de 1964, exigindo-se do Estado a responsabilidade pelo esclarecimento dos crimes, a criação dos comitês de anistia (em que se pede perdão aos familiares) e a reparação via indenização.

A Comissão de Familiares de Mortos e Desaparecidos Políticos e o grupo Tortura Nunca Mais apresentaram, ainda em 1995, documento à Comissão Interamericana de Direitos Humanos (CIDH), da Organização dos Estados Americanos (OEA), pedindo a intervenção para a identificação e punição dos responsáveis. Essa decisão embasava-se em outras tomadas para casos semelhantes em toda a América Latina e no próprio Estatuto de Roma, de 1998, em que se defendia o direito de todos ao acesso de informações e à punição de crimes contra a humanidade, como a tortura e o desaparecimento forçado:

"[...] a Corte considerou que leis de autoanistia perpetuam a impunidade, obstruem o esclarecimento dos fatos, propiciam uma injustiça continuada, impedem as vitimas e a seus familiares o acesso à justiça e o direito de conhecer a verdade e de receber a reparação correspondente, o que constituiria uma afronta direta a Convenção Americana. Dessa maneira, as leis de autoanistia configurariam um ilícito internacional e sua revogação, uma forma de reparação não pecuniária. [...] a Corte decidiu pela invalidade de decreto-lei do período ditatorial, por implicar a denegação de justiça as vitimas e por afrontar os deveres do Estado de investigar, processar, punir e reparar graves violações de direitos humanos. [...] O jus cogens resiste aos crimes de Estado, impondo-lhe sanções”. Na America Latina, há significativa jurisprudência a respeito da imprescritibilidade e não aplicação de leis de anistia em relação a crimes de lesa-humanidade, como ilustram os casos de Argentina, Chile, Peru, Colômbia e Paraguai. (COMISSÃO NACIONAL DA VERDADE, 2014, p. 966)

\section{CANPHLAC}

Revista Eletrônica da ANPHLAC, ISSN 1679-1061, No. 18, p. 223-250, jan./jul. 2015. http://revista.anphlac.org.br/ 
Em 24 de novembro de 2010, a Corte Interamericana condenou o Estado brasileiro por omissão em relação à responsabilização dos torturadores, à revisão da anistia e às políticas de reparação, determinando, entre outras coisas, que os autores de violações não se poderiam beneficiar da anistia enquanto as vítimas não tivessem obtido justiça, mediante um recurso efetivo, e que a Lei da Anistia deveria ser suprimida, sem representar obstáculo para o julgamento dos acontecimentos ${ }^{7}$. Nesse sentido, chamou-se o Estado brasileiro à responsabilidade quanto às ações de violação aos direitos humanos, cometidas pela ditadura civil-militar, o que apontou para a obrigatoriedade de criação de uma comissão nacional da verdade, como meio imprescindível para garantir o direito coletivo de conhecer a verdade sobre o passado, portanto, para a construção e preservação da memória histórica e para a garantia de que ações semelhantes de violência não se repetissem.

No entanto, após a Ordem dos Advogados do Brasil ter entrado com um pedido de revisão da Lei da Anistia, em 29 de abril de 2010, visando à imprescritibilidade dos crimes considerados de lesa humanidade, apenas dois ministros do Supremo Tribunal Federal compreenderam como necessário retomar a discussão em torno do passado. Os demais consideraram que a manutenção do "consenso social" (leia-se acordo unilateral) colaboraria para "evitar abrir a caixa-preta", de modo a impedir que "rancores e ressentimentos viessem à tona", promovendo-se assim a "reconciliação nacional", como forma de "se seguir em frente." 8

Aprovada em novembro de 2011 pelo Congresso Nacional, pela Lei no 12.528, a Comissão Nacional da Verdade foi oficialmente criada em maio de 2012. Apesar de ter ocorrido após 30 anos do final do regime autoritário, o tempo não diminuiu as obrigações éticas e jurídicas do Estado e da sociedade brasileira para com as vítimas que, na verdade, representam a coletividade nacional. A apresentação dos dados quantitativos e qualitativos pelos membros da CNV significa a efetivação de um longo processo de esclarecimento das graves violações de direitos humanos praticadas no período de 1964 a 1988.

\footnotetext{
${ }^{7} \mathrm{http} / / / \mathrm{www} . c o r t e i d h . o r . c r / d o c s /$ casos/articulos/seriec_219_por.pdf

${ }^{8} \mathrm{http}: / /$ www.stf.jus.br/portal/cms/verNoticiaDetalhe.asp?idConteudo=125515
}

\section{CANPHLAC}

Revista Eletrônica da ANPHLAC, ISSN 1679-1061, №. 18, p. 223-250, jan./jul. 2015. http://revista.anphlac.org.br/ 
Parte dessa demanda foi contemplada com a criação da Comissão Nacional da Verdade pela presidente Dilma Rousseff, que passou a funcionar em 2012, quando se ouviram testemunhos de vítimas e algozes e foram expostas à sociedade civil as dores históricas. No entanto, o formato da atuação de seus membros - que trabalharam de forma restrita sem poderem levar a julgamento os perpetradores -, a ausência de publicização mais ampla das audiências e a forma de reparação às vítimas - limitada a pagamento de indenizações e pedidos de desculpa - promoveu, e ainda promove, manifestações a favor de um encaminhamento mais democrático e justo dos resultados.

Ações judiciais contra perpetradores, como é o caso das famílias Teles e Merlino contra o coronel Carlos Alberto Brilhante Ustra, em 2013, para que fosse declarado torturador de seus familiares e responsável por seus assassinatos, promoveram debates mais acalorados sobre a possibilidade da revisão da anistia. Estimularam, inclusive, embates mais diretos entre setores diferentes da sociedade brasileira sobre o significado da data de 31 de março de 1964, nos quais envolveu-se parte considerável da juventude, por meio também das redes sociais e da ocupação dos espaços públicos no enfrentamento a apoiadores do regime.

As considerações da Comissão Nacional da Verdade, em extenso relatório, depois de dois anos e meio de investigação em documentos colhidos nos mais diferentes arquivos nacionais e internacionais e por meio de audiências públicas com testemunhas, assim como seus encaminhamentos - dentre eles, o estímulo a uma educação voltada aos direitos humanos nas escolas civis e militares - devem reforçar ainda mais o direito de saber, de recordar - que cabe a qualquer pessoa ou povo - contra qualquer tipo de revisionismo ou negacionismo histórico. Isso significa tocar em feridas tais como a impunidade, o trauma e o silenciamento forçado. Representa também a responsabilidade das novas gerações como mediadores entre passado, presente e futuro, como multiplicadores e também promotores da reflexão incômoda, porém necessária, sobre o país que fomos e o mundo que queremos ser.

\section{O Levante Popular da Juventude e os "esculachos" no Brasil}

\section{GANPHLAC}

Revista Eletrônica da ANPHLAC, ISSN 1679-1061, No. 18, p. 223-250, jan./jul. 2015. http://revista.anphlac.org.br/ 
O Levante Popular da Juventude foi um dos movimentos sociais juvenis que cresceram no Brasil, atraindo jovens de diferentes setores sociais e com grande espaço nas universidades, em torno da questão da memória sobre a ditadura civil-militar na América Latina e, em especial, no País. Suas primeiras manifestações aconteceram em Porto Alegre, em 2006, mas elas se expandiram em diferentes estados com inúmeros comitês, que seguem atuando até hoje.

De acordo com Silva e Ruskowski (2009), o Levante originou-se da ligação de jovens universitários e secundaristas com o Movimento dos Sem Terra (MST), quando se articularam várias ações sociais em torno da criação de bandeiras coletivas, com unificação de demandas rurais e urbanas. As primeiras discussões teriam surgido em um acampamento, na cidade de São Gabriel, no Rio Grande do Sul. Para os autores, ali foram lançadas as bases de sua organização, com a participação de camponeses, estudantes, indígenas e setores do movimento negro e religioso, tendo como tripé "educação, trabalho e cultura", direitos considerados fundamentais à juventude e aos quais ela deveria ter acesso.

Segundo os autores, o grupo nasceu no período de transição democrática, justamente da necessidade de criar espaços de debates dentro e fora das universidades, aproximando as ações e o discurso acadêmico das demandas sociais, numa relação mais democrática e popular com o movimento estudantil, sindical e campesino. Estrutura-se na ideia de células populares que se expandem e ocupam universidades, centros urbanos e rurais, entre outros, além de atuar em setores mais específicos, como grupos de feministas.

Além dessas demandas, o Levante Popular da Juventude acabou por criar comitês engajados no processo de pressão sobre o Estado, para a criação de comissões da verdade e ampliação do debate público sobre a ditadura civil-militar e suas heranças na sociedade brasileira. Influenciados pelos HIJOS argentinos e sob o mesmo lema "Se não há justiça, há esculacho popular", esses jovens passaram a colaborar na identificação de arquivos e de responsáveis pela violência, por meio da participação em eventos de discussão política e da denúncia, realizadas nos "escrachos" ou esculachos, como ficaram conhecidos no Brasil:

\section{GANPHLAC}

Revista Eletrônica da ANPHLAC, ISSN 1679-1061, No. 18, p. 223-250, jan./jul. 2015. http://revista.anphlac.org.br/ 
No Dicionário [25], a palavra escrachar é definida como: "1. Fotografar e fichar (na polícia); 2.Desmoralizar(alguém), revelandolhe as intenções ocultas; desmascarar; 3. Descompor injuriosamente; esculachar; esculhambar". O sentido que se enquadra ao vocábulo que dá nome ao movimento que ora analisamos é o da revelação das intenções ocultas da pessoa que é desmascarada. Esta, responsável por atrocidades num passado recente, não respondeu por seus atos no âmbito judicial, o que acarreta prejuízo para todos, inclusive os autores dos crimes, que poderiam ser processados com todas as garantias de defesa e que, em virtude da impunidade reinante, tornamse objeto dos escrachos (QUINALHA; SOARES, 2013).

Sua performance, principalmente entre 2010 e 2012, contribuiu consideravelmente para a luta em torno da criação da Comissão Nacional da Verdade e fortaleceu o debate democrático sobre o trauma histórico brasileiro. A ação de "esculachar" ou "escrachar" conta com a participação de inúmeros jovens que aliam a criatividade - barulho com instrumentos, poesia, artes plásticas, panfletagem, teatralidade, música, gritos de ordem como "aqui mora um torturador", entre outros - à reivindicação de justiça e à denúncia da omissão do Estado e da impunidade. Isso se tornou uma marca do Levante e dos outros movimentos similares. Com forte presença nas ruas, costumam pichar calçadas, muros e portas de casas com o nome dos torturadores que ali vivem, questionando o "perdão forçado" pela Lei da Anistia. Munidos de cartazes, faixas, megafones, panfletos, instrumentos de percussão, palavras de ordem e bom humor, inauguram novas formas de manifestação política, rompendo com pelo menos dois imaginários do senso comum: a existência da alienação política entre os jovens após a ditadura, caracterizada por desejos superficiais e hiperconsumo; e a ideia de que fazer política passa necessariamente pelas organizações sindicais ou partidárias tradicionais. Sobre essa nova forma de fazer política, afirma Ann Mishe:

No meio dos grupos organizados, também se vê uma complexificação marcante das formas de participação social e política, embora essas redes continuem a ser densas e entrelaçadas. Jovens com algum interesse político agora podem escolher entre muitas formas alternativas de militância, incluindo partidos políticos, movimentos populares, sindicais e anti-discriminatórios, organizações nãogovernamentais e associações profissionais. Desde seu reaparecimento nas manifestações pela democratização no final dos

\section{GANPHLAC}

Revista Eletrônica da ANPHLAC, ISSN 1679-1061, No. 18, p. 223-250, jan./jul. 2015. http://revista.anphlac.org.br/ 
anos 70, o movimento estudantil tem se engajado num processo conflituoso de reconstrução, embora ficasse politicamente marginalizado durante a maior parte dos anos 80 (MISHE, 1997, p. 139).

Numa nova forma de tomar o espaço público e de militar politicamente, o Levante realizou, no ano de 2012, 12 manifestações de "escrachos" em 11 estados do Brasil: Pernambuco, Pará, Bahia, Ceará, Sergipe, Paraíba, Rio Grande do Norte, São Paulo, Minas Gerais, Rio de Janeiro e Rio Grande do Sul, destacando-se aqueles dirigidos ao médico legista Harry Shibata, em São Paulo, que assinou diversos laudos de morte e forjou versões para a morte de opositores, como a de suicídio do jornalista Vladimir Herzog, além da organização no Guarujá, dirigida ao tenente-coronel Maurício Lopes Lima, reconhecido pela presidente Dilma Rousseff como seu torturador da Operação Bandeirante.

A performance política pela "memória, verdade e justiça" seguiu nos anos posteriores, intensificada em abril de 2014, quando diferentes versões sobre os 50 anos do golpe de 1964 se confrontaram mais abertamente. Enquanto segmentos conservadores da sociedade celebravam a "redentora" do dia 31 de março, vários jovens do Levante respondiam com novos esculachos, como aqueles realizados em Brasília contra o coronel Carlos Alberto Brilhante Ustra, ex-chefe do DOI-CODI; em São Paulo, denunciaram o ex-militar e delegado Aparecido Laertes Calandra (o Capitão Ubirajara), e em Belo Horizonte, em frente à casa do coronel Pedro Ivo dos Santos Vasconcelos, atuante do DOPS-MG e autor de inúmeros crimes entre os anos de 1969 a 1971.

Em dezembro de 2014, um dia após o relatório da Comissão da Verdade ter sido entregue à presidente Dilma Rousseff, o Levante organizou nova manifestação na rodovia Washington Luiz, pedindo a punição dos torturadores ${ }^{9}$. Cada uma dessas manifestações, organizadas em diferentes estados, é filmada e inserida nas redes sociais, numa forma cada vez mais criativa de informar e manter viva uma memória com a qual os jovens se identificam e da qual querem ser portadores e mediadores.

\footnotetext{
9 http://www.conversaafiada.com.br/brasil/2014/12/14/levante-interdita-rodovia-para-cobrar-punicao-detorturadores/ - Acesso em 15 de dezembro de 2014.
}

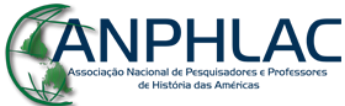

Revista Eletrônica da ANPHLAC, ISSN 1679-1061, № . 18, p. 223-250, jan./jul. 2015. http://revista.anphlac.org.br/ 
Esse passado, como memória, não parece ser compreendido pelos militantes do Levante, de forma estanque, cristalizado, mas como processo de contínua reinvenção a partir de experiências vividas por eles no presente. Assim também, as formas de lidar com as continuidades são recriações, em que novas práticas sociais e políticas são pensadas, mais elaboradas e performáticas, que trazem as marcas das rupturas geracionais/culturais e de interesses amplificados pelas demandas estéticas e físicas do corpo, do meio ambiente, da inclusão social, entendidas como parte dos direitos humanos. Sobre essa nova forma de fazer política no processo de transição democrática, Benevides e Luz afirmam:

Torna-se, portanto, essencial entender que a participação mais direta dos indivíduos, em geral, e jovens, em particular, na conjuntura atual, tem como característica mais marcante a pluralidade dos conteúdos e das formas de atuar, isto é, a utopia num contexto de interações sociais globalizadas significa estabelecer vínculos entre o particular e o universal e, assim, construir um mundo melhor para todos. Desta maneira, os indivíduos jovens de hoje vão reconstruindo o campo do político com suas práticas e valores inovadores, cujos modos de atuar têm exigido um engajamento mais cotidiano, por meio dos quais as culturas políticas são reconfiguradas. Um exemplo bem ilustrativo de como, hoje, a participação política juvenil tem reconfigurado as culturas políticas contemporâneas, especialmente no que tange às suas ações e manifestações voltadas para a defesa de múltiplas bandeiras que estabelecem um diálogo profícuo entre o particular e o universal e, ao mesmo tempo, mesclam formas tradicionais de luta com formas inovadoras, diz respeito ao Levante Popular da Juventude (BENEVIDES; LUZ, 2010, p. 3).

A terceira geração de memória, formada por esses jovens que participam do Levante, parece demonstrar o entendimento sobre a necessidade de repensar o passado, não pela perspectiva apenas factual, como algo que passou e acabou, mas pela força com que os acontecimentos políticos anteriores continuam a marcar o presente, inclusive a própria vida deles enquanto cidadãos da América Latina e do Brasil. A criação e atuação da Comissão Nacional da Verdade, assim como entenderam os filhos nascidos sob a ditadura argentina ou chilena, é apenas mais um passo para realização da reparação moral, jurídica e histórica de um mal cometido contra toda a humanidade.

\section{CANPHLAC}

Revista Eletrônica da ANPHLAC, ISSN 1679-1061, №. 18, p. 223-250, jan./jul. 2015. http://revista.anphlac.org.br/ 
Para muitos desses jovens, que atuam nas Universidades, embora não tenham vivenciado a experiência da perseguição, da tortura ou do exílio, a violência permanece nas práticas cotidianas, nas feridas que ainda sangram, e eles precisam tornar conhecida à sociedade essa memória traumática que também lhes pertence por afinidade, por afeto e por responsabilidade política quanto a um futuro melhor para sua própria geração.

\section{Considerações finais}

Memória, verdade, justiça e reparação. No contexto de justiça de transição esses conceitos ganharam cada vez mais força em países da América Latina, como Argentina, Chile e Brasil, marcados historicamente pelos regimes autoritários e pela violação aos direitos humanos, entre os anos 1960 e 1990. As comissões da verdade foram fruto de longas lutas sociais, de novas e velhas gerações, que procuraram legitimar o testemunho das vítimas como fundamental para evidenciar a necessidade de reconhecimento de crimes e violações no passado e que deixaram rastros no presente. Revelaram em sua constituição e atuação que a memória é campo de lutas políticas e coloca em jogo diferentes interpretações que implicam seleção quanto ao que lembrar e esquecer. A identificação ou não das novas gerações com a dor de pessoas também jovens que as antecederam pode ser decisiva na contribuição para a democracia política na América Latina.

Muitos silêncios ainda permanecem por diferentes razões: relacionados aos que vivenciaram situações limite e não querem se ferir ou causar mais ferimentos a outros; àqueles que pretendem cuidar e preservar seus entes queridos; para continuar vivendo; para evitar culpas; pelo temor de não ser ouvido ou compreendido pela apatia de parte da juventude diante do passado desconhecido e, por isso, incompreendido. Há também o silêncio enquanto direito de não lembrar. $\mathrm{O}$ esquecimento é seletivo, afirmou Pollak (1992), no sentido de poupar pessoas, apagar memórias indesejadas, dolorosas, comprometedoras, as humilhações e medos. Lembrar o tempo todo das perdas, mortes e torturas seria insuportável, mas esquecer também deve ser um direito precedido pelo desejo de conhecer.

\section{CANPHLAC}

Revista Eletrônica da ANPHLAC, ISSN 1679-1061, Nº. 18, p. 223-250, jan./jul. 2015. http://revista.anphlac.org.br/ 
Dessa forma, como lembrou Paul Ricoeur ao discutir perdão e anistia (2007), a anistia política instituída pelo Estado - no caso aqui dos regimes latino-americanos violou o direito das novas gerações de saberem do dolo, forjando uma amnésia institucional que convida a agir como se o fato não tivesse ocorrido. Todos os delitos do esquecimento em torno dos crimes cometidos contra os direitos humanos estão contidos nessa incrível - para não dizer "mágica" - pretensão de apagar os vestígios das discórdias públicas. Segundo Ricouer, como amnésia comandada ela dissimula um passado declarado proibido ao presente e ao futuro.

O jogo do apagamento forçado de memórias das vítimas, promovido pelo Estado autoritário ou pelos setores que apoiaram as ditaduras, não conseguiram, entretanto, provocar seu total esquecimento. Se os regimes ditatoriais tiveram sempre a intenção de calar e fazer desaparecer as pessoas e as falas, as vítimas insistiram na justiça de transição e no diálogo com o presente, fazendo o elogio ao testemunho e proporcionando ao jovem a oportunidade de ouvir e de se responsabilizar pela memória do outro que, afinal, também passa a ser sua. Sobre isso, afirmou Ricouer:

O dever da memória é o dever de se fazer justiça, pela lembrança, a um outro que não o si. [...] é chegado o momento de recorrer a um conceito novo, o de dívida, que é importante não confinar no de culpabilidade. A ideia de dívida é inseparável da de lembrança. Somos devedores de parte do que somos aos que nos precederam. $\mathrm{O}$ dever da memória não se limita aguardar o rasto material, escrito ou outro, dos fatos acabados, mas entretém o sentimento de dever a outros, dos quais diremos mais adiante que não são mais, mas já foram. Pagar a dívida, diremos, mas também submeter a herança a inventário (RICOUER, 2007, p. 101).

As sequelas psicológicas e históricas desse passado têm duração transgeracional, e por isso os acontecimentos devem ser conhecidos, debatidos e assumidos como história em aberto. A impunidade dos torturadores, a lei de anistia, a continuidade da opressão, em outros termos, a negação do reconhecimento social e jurídico dos danos sofridos, tudo isso deve fazer parte, como dívida e reconhecimento, da memória dos jovens, responsáveis também pelo porvir:

\section{CANPHLAC}

Revista Eletrônica da ANPHLAC, ISSN 1679-1061, No. 18, p. 223-250, jan./jul. 2015. http://revista.anphlac.org.br/ 
Pode-se sempre narrar de outro modo, suprimindo, deslocando as ênfases, refigurando diferentemente os protagonistas da ação assim como os contornos dela. [...] Recriar o que já passou [...] é uma experiência purificadora e libertadora, pois através da 'mágica da memória' pode-se ter a 'sensação catártica de botar para fora tanta coisa guardada, de exorcizar fantasmas do passado [...] (ARRIGUCI apud MALUF, 1995, p. 32).

Expor dores e abrir espaço para a narrativa-testemunho pode trazer alívio e, mais do que isso, pode tornar-se terapêutico se significar a releitura e a transformação do presente pelas novas gerações. No contexto atual de discussões sobre as comissões da verdade e as ações dos "escrachos" ou "esculachos" como denúncia de crimes e imputação de responsabilidades a todos os cidadãos, pode significar um grande "ajuste de contas" com a história. Experiências passadas e narradas podem transformar outras experiências a partir de seus resíduos, continuidades e ensinamentos.

Trata-se de saber que novos valores, ações e espaços são esses que estão sendo recriados por parcelas organizadas da juventude, seja no Brasil pelo Levante, seja no restante da América Latina. O que representa para esses jovens um passado histórico de violência e como projetam um modelo (ou vários) de sociedade democrática? Quais são suas utopias coletivas? Que tipo de militância, de engajamento, e que novas subjetividades e identidades estão sendo construídas por agrupamentos semelhantes aos HIJOS, na Argentina, ou ao Levante, no Brasil?

Se os danos sofridos e silenciados forem reconhecidos não apenas por quem os vivenciou, mas também pelos que vieram depois, e os testemunhos conseguirem instaurar a responsabilização e a reparação não apenas financeira, mas acima de tudo ética e jurídica, haverá um processo terapêutico coletivo, permitindo-se a inscrição social e elaboração do trauma histórico e a mudança diante da dor, antes restrita ao privado e agora publicizada, com a colaboração de diferentes setores sociais e de parte da juventude latino-americana, em especial.

Sustentar a ideia de "nunca mais" em relação ao passado não significa esquecer, deixar para trás o sofrimento de outros. Significa o desejo de que as barbaridades sejam lembradas no presente para não se repetirem jamais. Ao contrário da ausência de

\section{GANPHLAC}

Revista Eletrônica da ANPHLAC, ISSN 1679-1061, No. 18, p. 223-250, jan./jul. 2015. http://revista.anphlac.org.br/ 
utopias, projetos de futuro estão em formação, forjando e sendo forjados por novas identidades juvenis, entrecruzadas por uma multiplicidade de ações políticas à luz da aprendizagem com as experiências e traumas promovidos pelo regime autoritário brasileiro. O Levante Popular da Juventude é exemplo de que pertencer a uma geração não significa esquecer, ignorar ou silenciar o que veio antes. É possível, pelo processo de empatia e da vontade de conhecer as experiências das vítimas, compreender em que contexto se deram, significá-las num novo processo histórico e se apropriar do passado para transformar o presente e o futuro.

Desta forma, herda-se, enfim, não apenas a memória do outro pelo conhecimento e pela identificação com a sua experiência, mas também o desejo ético pelo respeito pleno aos direitos humanos, independentemente das gerações e contextos históricos.

\section{GANPHLAC}

Revista Eletrônica da ANPHLAC, ISSN 1679-1061, №. 18, p. 223-250, jan./jul. 2015. http://revista.anphlac.org.br/ 


\section{Referências Bibliográficas}

BAUMAN, Zygmunt. Comunidade. Rio de Janeiro: Zahar, 2005.

BENEVIDES, Silvio O; LUZ, Sóstenes A. Juventudes e participação: os atores de uma nova dimensão do político: o caso do Levante Popular da Juventude. 2010. Disponível em:http://actacientifica.servicioit.cl/biblioteca/gt/GT22/GT22_OliveiraBenevides_Aroei radaLuz.pdf - Acesso em 24.jul.2014.

COMISSÃO Nacional da Verdade. Relatório final da Comissão da Verdade. Brasília: CNV, 2014.

CUYA, Esteban. Justiça de Transição. Acervo, Rio de Janeiro, v. 24, no 1, jan/jun, p. 37-78, 2011.

HALBWACHS, Maurice. A memória coletiva. São Paulo: Centauro, 2006.

HARTOG, François. Tempo e Patrimônio. Varia História. Belo Horizonte, vol. 22, $\mathrm{n}^{\mathrm{o}}$ 36, Jul/Dez, p. 261-273, 2006.

MALUF, Marina. Ruídos da memória. São Paulo: Siciliano, 1995.

MICHEL, Johan. Podemos falar de uma política de esquecimento? Revista Memória em Rede, Pelotas, v.2, n. 3, ago-nov, p. 14-26, 2010.

MISHE, Ann. De estudantes a cidadãos. Revista Brasileira de Educação Mai/Jun/Jul/Ago 1997, nº 5 Set/Out/Nov/Dez, p.134-150, 1997.

NORA, Pierre. Entre memória e história: a problemática dos lugares. Projeto História, São Paulo, n.10, dez., p.7-28. 1993.

PASSERINI, Luísa. Memoria y utopia: la primacia de la intersubjetividad. Valencia: Universitat de Valencia, 2006.

PINTO, Simone Rodrigues. Direito à memória e à verdade: comissões de verdade na América Latina. Revista Debates, Porto Alegre, v.4, n.1, jan-jun, p.128- 143, 2010.

POLLAK, Michael. Memória e identidade social. Estudos Históricos, Rio de Janeiro, v.5, n. 10, p. 200-212, 1992.

QUINALHA, Renan H.; SOARES, Inês V. Os escrachos e a luta por verdade e justiça “desde baixo”. 2013. Disponível em http://revistavjm.com.br/artigos/os-escrachos-e-aluta-por-verdade-e-justica-desde-baixo/. Acesso em: 30 jun., 2014.

\section{CANPHLAC}

Revista Eletrônica da ANPHLAC, ISSN 1679-1061, No. 18, p. 223-250, jan./jul. 2015. http://revista.anphlac.org.br/ 
RICOUER, Paul. História, memória e esquecimento. Campinas: Editora da Unicamp. 2007.

RUSKOWSKI, Bianca de Oliveira; SILVA, Marcelo K. O processo de engajamento militante a partir do estudo sobre condições e mecanismos de engajamento. 2009. Disponível

http://actacientifica.servicioit.cl/biblioteca/gt/GT20/GT20_OliveiraRuskowski_Kunrath Silva.pdf. Acessado em 24/07/2014. - Acesso em: 30 jun, 2014.

SIKKINK, Kathryn. A era da responsabilização: a ascensão da responsabilização penal individual. In: COMISSÃO da Anistia. A anistia na era da responsabilização: o Brasil na perspectiva internacional e comparada. Oxford: Oxford University, 2011, p. 34-75.

\section{GANPHLAC}

Revista Eletrônica da ANPHLAC, ISSN 1679-1061, №. 18, p. 223-250, jan./jul. 2015. http://revista.anphlac.org.br/ 